\title{
Class, Agency, and Citizenship in Belarusian Protest
}

\section{Elena Gapova}

Belarus has a certain reputation: for the past quarter of a century, it has exemplified electoral authoritarianism, where regular "elections without content," whose outcome was known in advance, tended to reinforce Aliaksandar Lukashenka's regime rather than endanger it. ${ }^{1}$ While protests against fraud did take place (to be put down with the use of force), the "old" opposition did not enjoy broad popularity: its platform of rights and causes typical of late nations was not "clicking" with the post-socialist modernized polity on whose behalf it was proclaimed. In 2020, however, the situation was different even prior the election day, as creative, peaceful, and involved citizens began knocking on doors and queueing for hours to sign for their candidates of choice to be put on the ballot: a (former) banker (Victor Babariko), a (former) head of an IT conglomerate (Valery Tsepkalo), and a protest blogger (Sergei Tikhanovsky [Siarhei Tsihanouskii]). ${ }^{2}$

If, as Hegel famously wrote, the Owl of Minerva flies out at dusk, and the meaning and "intentions" of historical events become clear only through temporal distance, it is quite a challenge to theorize a social upheaval while it is still evolving; it is even more so with a state ban on collecting sociological data, as is the case in Belarus. However, the Belarusian revolution has triggered an intertextual conversation among scholars, activists, and social commentators across multiple digital platforms and national borders, with Slavoj Žižek arguing in The Independent that Belarusians are trying to catch up with western liberal democracy at the moment it is in crisis, ${ }^{3}$ and anthropologist Andrey Vozyanov replying with an open letter on Facebook. ${ }^{4}$ This ongoing act of collective knowledge production, where political engagement and professional reflexivity come together in a gesture of resistance to persisting authoritarian patterns in academia and the public sphere, has produced some brilliant insights first articulated in blogs, Facebook posts, or dropped in passing in discussion forums. I am deeply indebted to this "hive mind" in my effort to answer two questions: "who are the protesters, sociologically speaking?” and "what is their point, politically?”

1. Sofie Bedford, "The Election Game:” Authoritarian Consolidation Processes in Belarus," Demokratizatsiya: The Journal of Post-Soviet Democratization 25, no. 4 (Fall 2017), 381.

2. None ended on the ballot: two were arrested and are currently in KGB jail, and one had to leave the country.

3. Slavoj Žižek, "Belarus's Problems Won’t Vanish when Lukashenko Goes," Independent (August 24, 2020), at https://www.independent.co.uk/voices/belaruselection-lukashenko-minsk-protests-democracy-freedom-coronavirus-a9685816.html (accessed February 2, 2021).

4. See Facebook post by Andrey Vozyanov at https://www.facebook.com/andrey. vozyanov/posts/3227943123927058 (accessed February 2, 2021).

Slavic Review 80, no. 1 (Spring 2021)

(C) The Author(s), 2021. Published by Cambridge University Press on behalf of the Association for Slavic, East European, and Eurasian Studies. This is an Open Access article, distributed under the terms of the Creative Commons Attribution licence (http://creativecommons.org/licenses/by/4.0/), which permits unrestricted re-use, distribution, and reproduction in any medium, provided the original work is properly cited. doi: 10.1017/slr.2021.21 


\section{Classing Belarusian Protest}

Popular explanations of the unprecedented mobilization in Belarus tend to focus on the actors' agency as their capacity to act independently. Political commentators argue that a new, "non-beaten-up," generation has come of age recently as the state forfeited some of its control over polity ${ }^{5}$ and theorize the power of "connective action' that that digital media brings to life. Sociologists point to the empowering experience of volunteer activism during the first wave of the pandemic, when urbanites were organizing to collect money for medical supplies, distribute masks, and deliver free meals to doctors. A relative deterioration of the economic situation due to the pandemic is also a factor, although the Belarusian uprising is not a hunger revolt: the regime has been buying the grudging acquiescence of the population with the promise of a welfare state and relatively low economic inequality. While there is more than a grain of truth in the above points, they address, to use a Marxist term, "superstructure" or mobilization triggers that only come into play under certain structural conditions. With anti-authoritarian urban revolutions such as the one taking place in Belarus, where "the state authorities became identical with its repressive apparatus," certain demographic makeup and class divisions need to be in place for these triggers to ignite.

Clearly, the marches for fair elections, freeing political prisoners, and stopping state violence that took off after August 9 have been attended by people of various social backgrounds, age cohorts, and, although most populous in Minsk, have been spread across the country. On the first day, nineteen cities protested; in the first week, in reaction to police brutality, at least one hundred cities with a population over 5000 were mobilized, their density being a little lower in the east. ${ }^{7}$ Twenty percent of protesters are between the ages of eighteen and twenty-nine, and those older than fifty-five also comprise the same number, which is remarkable; protesters are also better educated than population in general. ${ }^{8}$ Most are Russian speaking; and the majority are not skewing to the wealthier of the country (and are less wealthy than those active in the Ukrainian Maidan), with women making fifty-five percent of protesters, and senior citizens and people with disabilities also

5. Artyom Shraibman, "Vyroslo nebitoe pokolenie," Euroradio (June 17, 2020), at https://euroradio.fm/ru/shraybman-vyroslo-nebitoe-pokolenie-i-vlasti-povyshayutcenu-protesta (accessed February 2, 2021).

6. Siarhei Biareishyk, "Election: Belarus at the Moment," Barricade: A Journal of Antifascism and Translation (January 7, 2021) at http://barricadejournal.org/ ramparts/election-belarus-at-the-moment/?fbclid=IwAR3zWoM6zDuS60G0hV87GRMf9vhqqt4CNf90w_w76upUa8dVtGCjQKSK08 (accessed February 2, 2021).

7. Emma Mateo, "From 'Glory to Ukraine' to 'Long Live Belarus': A Comparison of Mass Mobilization in Ukraine (2013-2014) and Belarus (2020)," YouTube video, posted by HURI, November 23, 2020, at https://www.youtube.com/watch? $v=j m 1 D 1 y i d X X E \&$ feature =youtu.be (accessed February 2, 2021).

8. Andrey Vardomatsky, Vadim Mozheiko, Anton Rulev, "Novaya sotsiologiya dlya novoi Belarusi”, Nashe Mnenie, March 15, 2021 at https://nmnby.eu/news/ discussions/7360.html?fbclid=IwAR3Y2fZbKATJzFn_g5ZowrfcyhTQ19If7oYXlnXx HEKjSEPhWrkx0oZhpw (accessed March 16, 2021). 
participating. ${ }^{9}$ While the social texture of protests is diverse, its driving force has been urban "Russian-speaking intelligentsia and new groups: teachers, university professors, creative types, cultural and media professionals, and a lot of people from information technology (IT)."10 This is one reason why the new candidates-successful professionals and public figures, educated, witty, and trying to live up to their declared principles-turned out to be so appealing: new urban educated groups could identify with them and see them as aspirational versions of themselves. The question is, however, how to inscribe a banker and a precarious "hippie" artist into the same group. An obvious temptation is to cautiously resort to "new class" theory: can it be adapted to the peculiar reality of Belarusian state capitalism?

The notion of "new class" came into being with the rise of professional, intellectual, and expert elites in the twentieth century, somewhat displacing purely economic definitions. Currently, the concept of class has come to imply social divisions, privilege, and exclusion based on non-economic distinctions produced through cultural outlooks and implicated in the modes of exclusion and/or domination created by the various forms of capital and even the power of discourse. Thus, class has become a broad organizing concept for theorizing a wide range of issues associated with inequality and differentiation that are sustained with differences in educational background, occupation (ways of procuring sustenance), lifestyle, culture, access to non-economic resources, and so on. ${ }^{11}$ In the post-socialist region, "new class" formations have been coming into being alongside the transition to a market economy and inclusion into global capitalism.

Applying this reasoning to the Belarusian case, it appears that the "unbeaten" generation can be of the "new class" nature (though age matters, too), whose members use intellectual, cultural, and educational capital to produce an income and sustain privilege. ${ }^{12}$ Most protesters are skilled professionals, with two groups standing out. One is made up of those employed in the Belarusian IT sector, which is a remarkable success-story with its beginnings in the Cold War. The Soviet government had invested heavily in defense research and development (R\&D), and after socialism, highlytrained personnel and the system of education made Belarus an outsourcing destination for western high-tech companies. IT has grown into a powerful sector of the economy after a boost in 2005, when it was granted tax breaks and special preferences. Currently, Belarusian IT makes up 5.6 percent of the Belarusian GDP and creates almost fifteen percent of all new jobs, with, for

9. Olena Onuch, “From ‘Glory to Ukraine’ to ‘Long Live Belarus'...,” YouTube video, posted by HURI, November 23, 2020, at https://www.youtube.com/watch?v=jm1D1yidXX E\&feature=youtu.be (accessed February 2, 2021).

10. Oksana Shelest, "Belorusy gotovy k dolgoi bor'be. Sociolog o nastroeniiakh protestuiushchikh," Deutche Welle, August 26, 2020 at https://www.dw.com/ $\mathrm{ru}$ /belorusy-gotovy-k-dolgoj-borbe-sociolog-o-nastroenijah-protestujushhih/a54704307?fbclid=IwAR0SRaB_ZG0rMLwcI6NFdgcaG91vGStMDixtZv2qUj86xlYS_vomk_ gTRfk (accessed February 2, 2021).

11. Wendy Bottero, "Class Identities and the Identity of Class," Sociology 38, no. 5 (December 2004): 985-1003.

12. Lawrence Peter King and Ivan Szelenyi, Theories of the New Class: Intellectuals and Power (Minneapolis, 2004). 
example, EPAM Systems, one of the largest software developers in eastern Europe, which trades on NY Stock Exchange. ${ }^{13}$ "Itishniks," a prominent group due to their grasp of expert and economic capitals, are united by their unique relationship to the technological base of the contemporary global economy. Another important faction of protesters is the educated precariat, many of whom are freelancers who get their sustenance from the global media market or ad hoc projects coming their way through international ecological, human rights, or feminist informational networks. Their employment depends on their inclusion in project-based networking, independent content production based on one's own resourcefulness, and making oneself "interesting."

At first glance, Belarusian political divides seem to follow the line of the "method" of income attainment (in the Weberian sense), with the postindustrial service and creative economy on the one side and those who depend on the state for their livelihood or are employed in manufacturing on the other. However, this neat picture is diluted by industrial workers who made up about twenty-one percent of protesters in the first week. There are more than a million people occupied in manufacturing in Belarus, where Soviet-era industrial giants have been "kept" and reoriented for the Russian market: except for "Belneftekhim consortium (oil processing) and Belaruskali (one of the world's largest manufacturers of potash fertilizers), Belarusian state-owned enterprises are mostly uncompetitive precisely because they are 'burdened' by the government with social functions" of providing jobs and benefits and are subsidized. ${ }^{14}$ While workers' involvement in protests was triggered by horrendous police brutality (tens of their comrades from the shop floor were detained and injured) and subsided with time, as workers' risk of job loss and persecution are higher than in information economy, their "grievances" remained, as proven by continuous efforts to go on strike.

Thus, it can be suggested that a political dividing line separates two "mega-classes" produced by a peculiar post-Soviet state capitalism. On the one side are those who are "included in the system" and on the other those "outside the system." ${ }^{15}$ Inclusion and exclusion are not defined by occupation alone (although it matters): a driver for a high-rank state bureaucrat would be "included," while an entrepreneur with no government connections is excluded (constantly being under threat of arrest on arbitrary charges). Those inside the "system" collectively control the state, have access to wrangling public money, and are the beneficiaries of state capitalism. The "system" also controls how the law is applied (or not applied) and defines and imposes "state ideology," a loose doctrine of patriotism and loyalty to the government

13. National Statistical Committee of the Republic Belarus at https://www.belstat.gov. by/ofitsialnaya-statistika/makroekonomika-i-okruzhayushchaya-sreda/informatsionnotelekommunikatsionnye-tekhnologii/ (accessed February 2, 2021).

14. Kseniya Zaika, "Some Thoughts on the Failure of National Strike in Belarus," Leafteast, January 6, 2021 at http://www.criticatac.ro/lefteast/some-thoughtson-the-failure-of-the-national-strike-in-belarus/?fbclid=IwAR1i_Z9GCv7cou_ou s7IQv6gzmcU9eK_BEwjJZr-ECDwfFnlxk89Qa2J48\#.X_XHAkZZllg.facebook (accessed February 2, 2021).

15. Vladimir Pastukhov, "Revoliutsiia otkhodit s Belorusskogo vokzala," Novaya gazeta, September 18, 2020 at https://novayagazeta.ru/articles/2020/09/14/87084revolyutsiya-othodit-s-belorusskogo-vokzala (accessed February 2, 2021). 
(or, rather, the president) that is taught in schools and universities and promoted by state-run media and art. Thus, the "system" has control over as much social space as it can embrace. This explains why doctors (employed in the state sector, but not integrated into asset control) are among the protesters (they are also aware of the scale of violence as they treat the wounded) on par with petty entrepreneurs and loosely-employed creative types, while state bureaucrats, university administrators, local government officials, and those in government-sponsored "show business," who get their sustenance from propagandistic programming on state TV are on the opposite side. In terms of their professional competencies, all artistic types should be in the same class; in reality, they belong to different resource groups. The ultimate "owner" of this nation-state corporation is President Aliaksandar Lukashenka, relying on the military and law enforcement.

\section{“Class for Itself”: Agency and Citizenship}

In August, a friend of mine took a video of a peaceful afternoon march in Minsk. Headed by Catholics (signing psalms), it took off from a plaza near a Russian Orthodox Church; a group of LGBT activists followed, then came anarchists and multiple non-aligned citizens and activists of all "shapes" and orientations. If protest is a form of political communication, ${ }^{16}$ what message might be common to this diverse group? Put somewhat differently, what made those seventy percent of protesters, who had never participated in protests before, join them?

More than a century ago, Yanka Kupala penned a poem that reads: "And, Say, Who Goes There?. . Byelorussians!. . . And what is it, then, for which so long they pined, Scorned throughout the years, they, the deaf, the blind? To be called human!"17 The poem is now a classic and in school anthologies, while the phrase "To be called human" has become an idiom. It is to this phrase that many protesting workers resorted (or, rather, it popped up "automatically") when talking to their city authorities and state enterprise administrators at the peak of the protests. This happened at the "Grodno-Azot" chemical plant; at the mines in Soligorsk; in a public conversation with the Head of the (token) Parliamentary Commission on Human Rights, and elsewhere. In Hrodna, a worker stressed when addressing the city mayor: "At this moment, we are not putting forward any demands of [raising] wages or providing us with adequate work gear. .."18

It is astounding how often protesters resorted to the vocabulary of dignity and worth (and sometimes, choice); at one climatic moment, philosophers performed a public reading of John Locke's work on liberty in a plaza in downtown Minsk, with the phrase "“Men being. . by nature, all free, equal and independent, no one can be. . subjected to the political power of

16. Mischa Gabowitsch, Protest in Putin's Russia (Malden, Mass., 2017), 51.

17. Yanka Kupala, “And, Say, Who Goes There?” (1906), translation by Vera Rich at https://allpoetry.com/And,-Say,-Who-Goes-There- (accessed February 2, 2021).

18. A worker speaking at a rally, "Rech' rabochego na zabastovke v Belarusi," YouTube video, posted by Nastoiashchee Vremia, Siuzhety, August 17, 2020 at https:// www.youtube.com/watch?v=OEcbOimyT60\&t=71s (accessed February 2, 2021). 
another. .." ringing in the air. However, dignity is almost a buzz word now. Ukrainian Maidan has been called "a revolution of dignity"; identity groups worldwide campaign for various causes for the sake of the recognition of their dignity, and so on. Sill, dignity (honor, worth) is a tricky concept: what kind of "substance" does it signify in the Belarusian case? Having analyzed a plethora of qualitative sources, I believe that it stands for group agency, from which self-awareness results and recognition is earned. Throughout several months, protesters have done more than march in rallies (which, as of early March, has become dangerous), embracing other "regimes of engagement" (to use Mischa Gabowitsch's phrase). They campaign for political prisoners and collect money for the persecuted; they turn their residential areas into "agoras" where poets, musicians, and intellectuals perform; they paint subversive graffiti on public surfaces (which the police violently destroy); they hang up protest flags and, as the police remove them, they make statements with women's underwear in "political colors" (white, red, and white panties in succession) on clothes lines on their balconies and so on. "Itishniks" who possess expert capital rooted in specific competencies, which in the era of global labor force has become a basis for economic capital, are particularly involved. Those of them who had left Belarus for Silicon Valley have started the Belarusian Solidarity Fund (BYSOL), to which anyone can contribute, and which provides financial assistance to "anyone who was repressed, persecuted, or lost their jobs for participating in strikes and peaceful protests in Belarus." 19

These activities, with their "mundane," everyday character, sustain identity formation. Protesters stress that they do what they do exclusively of their own volition. As a protester explained on Facebook, "the old opposition [which formulated slogans and ideologies and did political organizing] was trying to give us back our rights, while the new one has given us back to ourselves." They said: "You know what you need to do. Go and do it."20 In other words, protesters act as free and autonomous subjects trying to make themselves heard or, rather, seen; by doing this, they achieve self-awareness and become "themselves," that is, who they believe they are. This signification has political meaning, as it is related to political subjectivity or citizenship, which stands for the status of a person in her political and legal relationship with the state. (Liberal) Citizenship implies autonomy, the recognition of an individual as an equal partner, and her ability to confront (and sue) the state. According to the sociologist Oksana Shelest, multiple informants named the impossibility of (personal and professional) development, of what they saw as therealization of their life project as their main grievanceagainst Lukashenka's regime. ${ }^{21}$ The quest of emerging political subjects for a new social contract with the state that would be based on the recognition of their voice and rights

19. Belarusian Solidarity Foundation at https://bysol.org/english (accessed February 2, 2021).

20. Posted by a protester on Facebook Sept. 21, 2021 under the "Friends only" mode and anonymized here.

21. Andrey Vardomatsky, Vadim Mozheiko, Anton Rulev, "Novaya sotsiologiya dlya novoi Belarusi”, Nashe Mnenie, March 15, 2021 at https://nmnby.eu/news/ discussions/7360.html?fbclid=IwAR3Y2fZbKATJzFn__g5ZowrfcyhTQ19If7oYXlnXxHEK jSEPhWrkx0oZhpw (accessed March 16, 2021). 
is exemplified by the case of Vadim Prokof'ev, a famous restauranteur and public figure who left Belarus but has since been recording and putting on YouTube popular videos in which he confronts the President with political demands. Back home, he could live comfortably, but to participate in political citizenship, he had to leave.

Is the quest for participation in political decision making, which is at the center of the Belarusian revolution, related to the reorganization of class structure? As Aristotle made us believe, having ascribed citizenship to free males (who had access to agency), one becomes a citizen as a member of a class or group. These days, however, social scientists hardly think of classes as "prêt-a-porter" communities with "objective" traits but as something that people do: class can be seen as a collective achievement as it is coming together in the "making" of itself for itself, when "signification follows from the struggle for signification." 22 "To an extent. . .class itself is not a thing, it is a happening," wrote Edward P. Thompson in The Making of the English Working Class. ${ }^{23}$ In this context, it is telling that Belarusian protesters often come out into the streets and make statements in cyberspace as members of work or professional collectives: as groups of doctors, teachers, university professors, musicians, and writers. This is so because so far (and this is one legacy of socialism), they have been "respected" and recognized in their capacity as workers contributing to the common good. At this point of transition to a different social contract, the members of Belarusian society are seeking ways to enter citizenship as a universal, however not unproblematic, category, in their capacity as autonomous political subjects.

22. Jana Tsoneva, "The Making of the Bulgarian Middle Class: Citizens against the People in the 2013 Protests” (PhD diss., Central European University, 2019).

23. Edward P. Thompson, The Making of the English Working Class (New York, 1966), 9. 